\title{
B-Cell Receptor CD22
}

National Cancer Institute

\section{Source}

National Cancer Institute. B-Cell Receptor CD22. NCI Thesaurus. Code C17279.

B-cell receptor CD22 (847 aa, $\sim 95 \mathrm{kDa}$ ) is encoded by the human CD22 gene. This protein is involved in B-cell/B-cell interactions and downstream signaling. 